\title{
The Impact of Students Intelligence Performance, According to Market Needs and Management of Reseources
}

\author{
PhD Evis Çelo
}

\author{
Prof. Assoc Dr Alba Robert Dumi
}

\author{
Department of foreign languages, Faculty of Human Science, "Ismail Qemali"Vlore University, Albania \\ Email:evis.celo8@gmail.com \\ Dean of Graduate School, "Ismail Qemali"VIore University, Albania, University of Tirana, Albania, Management Department \\ Email:alba.besi12@gmail.com
}

\section{Doi:10.5901/ajis.2015.v4n3s1p336}

\begin{abstract}
Within the living civilization and the Post-Modern society, knowledge and management became the main fundamental resource. Over the last decade there is a growing role in the schools and universities perception and the society by which extensive reforms have initiated in the university system. However, the arised question here is: Do we really possess the conditions, the research or sufficient safety, so that the science student can confront the growing demands trade market? Meanwhile the trade market and employers organize their tests, hence the question naturally comes, how does these capable students by their scientific capacity can influence in developing a) the universities they derive from b) on the whole universal managing system as a global phenomenon c) the real post-industrial society and if self- accomplishments have benefit of twoway? This analytical article focuses on some dilemmas and on some data as much empirical as real based on statistics about how the universities react and display under the influence of these management challenges. What are the solutions or measures in higher education (e.g University of Vlora) that prepare and prevent drastic extremity of intelligence loss in the trade market? What are the basic differences in university education (e. g University of Vlora) and its role in society based on knowledge, intelligence and management of trade markets?
\end{abstract}

Keywords: Inteligence analysis, drastic extremity, culturally - social - scientific aspect, Post - modernism, student cualification and level.

\section{Introduction}

In Albanian new state where the process of democratization was rapidly enough, standard schools and universities have always been special and by specific goals for mankind and society itself, where knowledge and education is becoming a vital problem for the family itself and government too. In our country (Albanian system) reforms in higher education are intensified including state and private universities. Private capital assets penetrating the trade market despite bearing collegiate level, despite weaknesses, conditions and new offers. Initiating by this Education is strongly influenced by external factors and therefore what happens in the global economy will certainly have its effects also in the quality preparation of generations for an enlighted society and for new professions.

New challenges in education research field in Albania give us an overview of restructuring universities with a continuous growth of private initiative which brings competition and the increase of student quality intelligence.Meanwhile it has raisen up numerous debates of economy experts and of university instructors (in our case Vlora University) who has encountered this problem and students themselves that have implemented the Bologna process following sustainably the principles of Salzburg!

By all the problems that has surrounded us; the challenge of intelligence competition in the trade market is the basic notion for a guide to solve the dilemma between the connection students Intelligence - University capacities - Trade markets management. This kind of relations in terms of contextual connection with literature review will continue with the development of hypotheses. 


\section{Literature Review and Hypotheses}

\subsection{Education in terms of post-modernism}

Peter Drucker, Alvin Toffler, Alexander Bell and many others have elaborated for the development of modern society. Along their writings about social order, it is called by different names: as the High -Tech information society, knowledge society, Fast- service society. Ducker says that today knowledge becomes the dominant economic resource. In terms of a great penchant to be educated at higher levels "the knowledge" appears as the only meaningful resource. Increasingly, in recent years, employers have succumbed to an urge use "labor relations consulants," who are usually either lawyers or psychologists, to prevent a union from gaining bargaining rights or to get rid of an established union through a decertification election (about which more will be said in chapter 3). Informed estimative place the number of such consulting firms at an absolute minimum of 1,000 , with at least five times that number of individuals directly involved in what unions bitterly call "union busting" and many employers contend is merely the providing of assistance to employees who genuinely want a nonunion environment.The AFL-CIO itself believes that a staggering of 75 percent of all managements now turn to these consultants expressly to gain help by unionization and that they pay them over $\$ 100$ million each year.Others would place these latter figures at lower one, although still stay in significant levels. Some members of this new growth industry at times advise their employer-clients to engage in activities that are quite illegal under national labor policy, harassing and discharging union members; avoiding the hiring of blacks (who are -in the opinion of at least one practitioner in this line of work.

Given the current state of labor relations law,as this paper research will explain in much more detail, consultants have a wide area of lawful tactics and strategies to place at their clients'disposal and by no means need move beyond what public policy allows in order to be effective. In addition, providing such personalized services, some consultants hold seminars open to all comers for a fee. Favored topics here are "Making Unions Unnecessary," "Avoiding Unions," and "Putting the Union Organizer on the Defensive," Members of the profession also produce a wide variety of articles, books and cassettes that find a lucrative market among antiunion managements (Kollin A, JERMS USA 2013)

\subsection{Learning resource orientation}

Traditional resources such as land, natural resources, labor, capital and property will not disappear, but will lose their importance will deviate as a secondary position. Sometimes, all this was mentioned as summarized in the term Postmodernism! Meanwhile the term post-industrial is used by Daniel Bell and Alain Touraine U.S. in France (Bell, D, 1993, Touraine, A.1994). So in reports of human as worker, environment and mangement we can conclude that it is future society, digital society, the society of micro- processor. The phenomena characteristics is the way of good productivity based on computerized factories, robotics industry, with a few words in machines.

The organizations are under pressure to show return on investment for training and development. Although positive trends, problems which management is faced are more challenging than the degree of preparation and performance that they offer, so their qualitative qualification remains the continuous preoccupation as the role of school and universities is in this direction. In this point of view education in distance can be considered as complementary approach and in some conditions as a worthy replacement of direct education, which still dominates educative systems in Albania. This paper research overview of the leader behavior literature highlighted the fact that there are inconsistent relationships between the behaviors that leaders engage in and the effects of these behaviors on member attitudes, behavior, and group effectiveness. Making decisions is fairly simple if no responsibility is attached to those decisions. True leaders always assume the responsibility for their actions, their plans, their programmer and their decisions. Courage and personal honesty, the marks of leadership, will permit nothing else. Albania like the other transitional countries is left behind from the western countries concerning the real understanding of the term "management". Also, management and the entrepreneurship skills are still considered as resources less efficient than capital assets in a moment when management and entrepreneurship play a crucial role in business success and performance.

\subsubsection{The public sector should offer enhanced employability}

A critical issue in the public sector's attractiveness will be the future career prospects of those entering. A good career no longer means a "job for life": the most important guarantees relate not to security but to employability. Any training offered as part of a recruitment package should have portability or link to a recognised credential, like the new generation 
of parttime MPA degrees. This could form part of a "development guarantee" to the individual. Work experience gained should be clearly relevant to a wide range of employers. Beyond that, the existence of known career paths and the prospect of promotion based on ability (rapid, where merited) would help position the public services as attractive employers: Transversal policy departments such as the DPSA and National Treasury should follow up, as part of their policy mandate, on those areas where most departments assessed themselves as noncompliant, to determine the underlying reasons for the non-compliance and develop appropriate responses to address these issues. This may require a review of the framework in that area of management. A key concern in this regard is the management performance area of service delivery improvement.

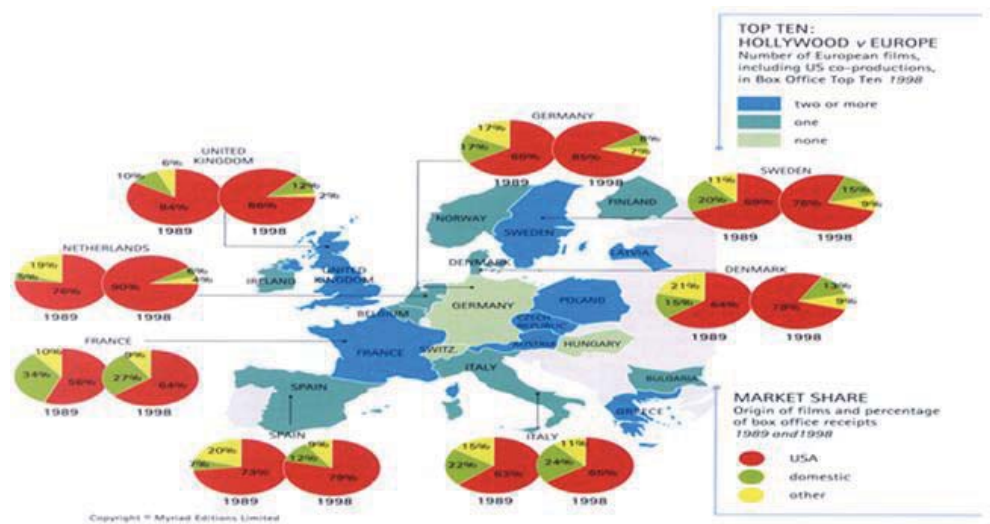

(Dumi A, MJESS Roma Italy, 2013)

\subsubsection{Management philosophies toward this intelligence in trade market and unions.}

Too many different roots of management opposition and the pervasiveness of so many of these requiements in trade market, it is tempting to speculate, the basic attitude of most bussines enterprises must be one of intransigent hostility. Meanwhile this presumed attitude, in other words, to be stated as an official policy, it would be expressed approximately as,"We seek to weaken organized labor by any and all means at our command, to frustrate it in its demands, to grant it nothing that is not absolutely necessary, and under no circumstances to make any attempt at accepting the union as a permanent part of our employee relations. If we adhere to this approach consistently and with sufficient patience, our workers will see that the union offers nothing. And they will ultimately arise and vote the union out at least as enthusiastically as they have voted it in."

There can be no denying that some executives do espouse this policy, as above, and that at an earlier time in American Labor history, many managers did so.The irony of contemporary labor relations and the intelligence in trade market, however, is that despite management's continuing opposition to unionism, its use of consultants, and its constant resistance to new labor inroads, much of the employer community has substantially departed from such a provocative stance.It has moved instead to what Lloyd Reynolds has called a "defensive endurance" philosophy:"If this is what our workers and others to be employed want, I guess we'll have to go along with it." In a word, the union is accommodated, however unwelcome and even unpalatable its presence may be.Management remains ever on guard as to "matters of principle," seeks to prevent the union from "intruding" in areas that are "the proper function of management," and frequently is highly critical of certain union actions. When people speak of "maturity" in labor relations, they are frequently thinking of this rapidly growing managerial posture and organized labor's relationship based on trade market requirements.

\subsection{The dominance of the market need, management implementation.}

Depending on such results while physical engagement is shifting in the direction where information service becomes the basis of productivity the lifestyle changes, education as a result of these movements should change the qualifications which will be acquired as a result of the process of new generation education and treatment of students' intelligence. What are the future qualifications demands? 
a) Industrial order - dominates production in trade market.

b) Post-industrial order- dominates the service managements.

c) Post-modernism - dominates the market and managements.

As a result it is not the main one the worker or the employee, eventhough occupying the largest number. From now and on, the future they will be qualified in the field of information technology, computers science etc. (not in what they inspired to study). This is according to Bell the codified knowledge predetermined by numbers, symbols, rules that move, controlled and disseminated by a great speed-distance coordinated systematic information! The distributors, the new social groups of this development strategy, as well as practitioners could be scientists, computer scientists, economists and specialists of all kinds. (Based on Gidens 2002)

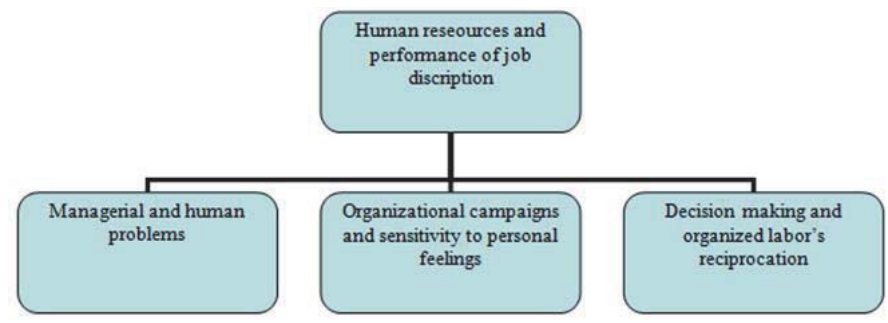

Source: Alba DUMI, AIJS Journal Roma Italy, " The role of university in reform of public sector" 2012, pp 135

And even among the more general of these different philosophies, at least six separate types (including the two above) can be distinguished.

1. Conflict, or the intransigent, uncompromising attitude depicted previously, is now fast fading from the labor relations scene.Nonetheless, this attitude existed on a wide scale prior to World War II.

2. Such a managerial stance arose to a great extent because many companies had been newly organized before that time, and because union organizational campaigns have never been notable for their sensitivity to personal feelings. Unions rarely resist the temptation in these circumstantes to engage in negative stereotyping of those who run the organization. The top managers are painted as ruthless, greedy profiteers, ready to do almost anything to increase return on investment and wholly insensitive to the most obvious of human problems. Any actual incidents that might support such charges are, of course, produced as accompaniments to such charges, but luck of available evidence is not necessarily any obstacle at all.

The union, consequently, does more than"undermine employee loyalty to the company"at such a time; it frequently goes well beyond the borders of the factual and bruises management egos in the process.Add managerial fears of decision making encroachments and of union values that are antithetical to those of management, as well as the other grounds for management's opposition to unionism on top of such an emotion-charged atmosphere, and it should not be surprising that many companies in the period immediately following their unionization embraced a philosophy of "no acceptance"of the union.

\subsubsection{Management labor relations philosophies, one important point of development}

Only in the face of the law universities and union power could extract concessions from such managements, and then only quite begrudgingly and on as temporary a basis as possible. Some companies and an ever-growing number of public servants are,of course, even today among the newly organized. Obviuosly, it is in the labor relations of these, indeed, that one is most apt today to encounter the Conflict philosophy. But this managerial attitude is not confined to new bargaining relationships: A minority of long-organized companies also currently adheres to it, owing to changes in management personnel, changes in union personnel or various other factors including the particular management's sheer refusal to abandon the hope that if unions are never really accepted by their companies, they will eventually also lose acceptance from their worker-members. In recent years, various newspaper publishers throughout the country have seemed, to many observers, to epitomize this latter situation.

In order not to miss out the students' intelligence on the market trade, but trying to manage it, as long as postmodern society is having increasing demand for excellent intelligence feeds, our University with the implementation of the Bologna process and the principles of Salzburg, where the best enterprises have been the universities themselves 
and students in free entreprenural. (Protocol of the Ministry of Education, October 2013)

The upward rubric requires to responding on how the scientific capacity affect in developing a) the universities where they come from b) on the whole universal managing system as a global phenomenon c) in actual society, in postindustrial ones and if self- accomplishments have benefit of two-way? As far as University of Vlora part of globalized managerial competences has undergone a series of political and institutional reforms students are closely connected with social and economic development, farther more in what way this intelligence is infiltrated to our university system as employee in other areas.

Protocol for higher education October 2013) Refering the literature review and upon the statistical scales the hypotheses represented as below:

H1.The reforming process of the university system (with management strategies of Markets) associated with intelligence development prospects.

H2. Some estimates on the preparation of students for their entry into the market and the role of the University of Vlora in this formation. system.

H.3The quality of higher education under real socio-economic impact, new research in managing university

An Important role that is considered as characteristic of innovation in Albanian education has been the private universities by their private competitive managing substanzas and their social role in increasing the richness of the offer and widening up the approaches for students. Statistical sources can extract these trends;

1) In Albania 4 years ago the number of students in private universities has increased for $28 \%$ with increasing tendency for each year (983 students in 2007 and 12,166 in 2008, 14,834 in 2010, 15,000 in 2012)

2) In 2008 Albania has had 11 public universities and 17 are private Universities. In 2008 only 4 of them has been validated and then their number has increased.

3) According to the Statistical Office of the Republic of Albania in the academic year 2008-2009 are recorded 63.437 students total of which $81.6 \%$ in state universities and $18.4 \%$ in private universities.

4) By the total of 1025 students of Private Universitites form 2007-2012 and State universities only $15-20 \%$ of them are employed not on their profile they were gradutated for, and about $40 \%$ are immigrating other $40-45$ $\%$ are unemployed.

Such evidences have pushed us on such extend and approaches including experience,cost of studies which has non balance curves in such unstable circumstances that the Albanian system has undergone rapidly enough. (Statistics that are used are taken from the Law State

\section{Methodology}

\subsection{Research Goal}

In this survey our goal is to identify and specify the universities reaction under the influence of managements challenges, a complex relation between Intelligence students and trade market.In order to verify the proposition questionaires were conducted.

\subsection{Sample and Data Collection}

The surveys are conducted in Private University "Pavaresia" and in University of Vlora "Ismail Qemali" with 1025 students, particularly the students of excellent result and the Albanian Union of managers and even in Municipality of Vlora region south Albanian territory. All these Institution together have compteted the criterias (1) by the year 2007-2008 the Private University "Pavaresia" has got a real success from student's increasement, their intelligence and the rest, while state University of Vlora "Ismail Qemali" has had balanced increasement of students. (2)all the students that are not able of taking position and employed are put in the categories of immigrated people.(3) some students questionaires were not included more than 40 of them. However 2 Albanian union, Tirana Bank crew and Municipality staff where students have conducted their practises have surely been in these surveys. 


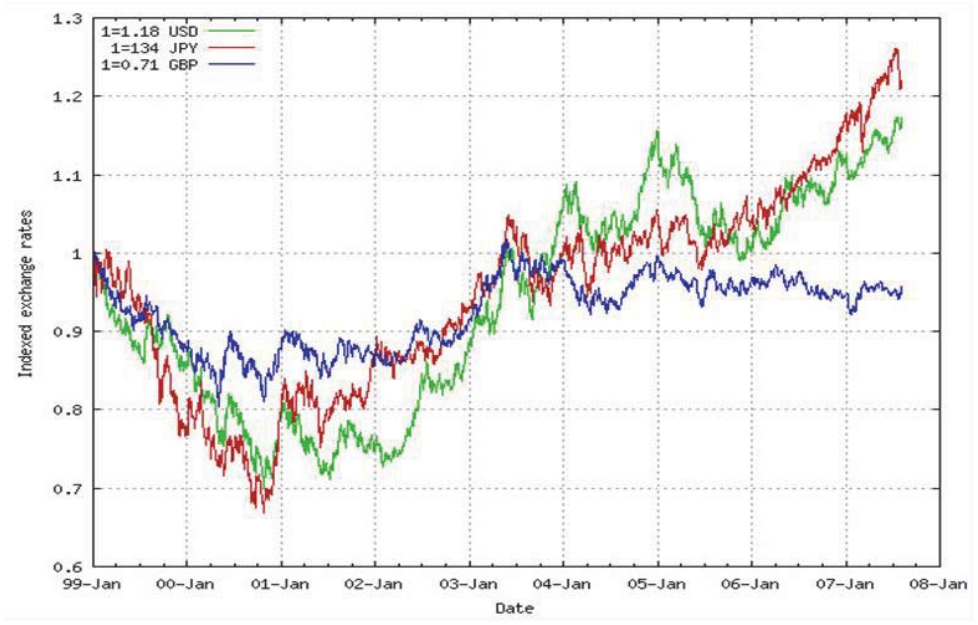

Source: Open Systems for Social Transformation, Toriccelli A 2014, Bokoni University Milano Italy

\subsection{Analyses and Results}

To measure the given evidences in higher education (e.g University of Vlora) that prepare and prevent drastic extremity of intelligence loss in the trade market we have used the chart evidences 2007-2010 and the diagrams. All these are adapted to the daily results and consequences that students especially students of excellence have done on Municipality and banking system (Tirana Bnak, memebership of Pireus Bank) and even for the rets of the students that emigrated due to the unemployment conditions

The table below represents.

\begin{tabular}{|c|c|c|c|}
\hline Students & years & Students increasement in Private university & Employement in the country and abroad \\
\hline 983 & 2007 & $6 \%$ & $2 \%$ \\
\hline 12.166 & 2008 & $5 \%$ & $3 \%$ \\
\hline 14.834 & 2010 & $8 \%$ & $3 \%$ \\
\hline 15.000 & 2012 & $9 \%$ & $2 \%$ \\
\hline
\end{tabular}

Table 1. Private University "Pavaresia"

\begin{tabular}{|c|c|c|c|}
\hline Students & years & Students increasement in State university & Employement in the country and abroad \\
\hline 42.122 & 2007 & $8 \%$ & $3 \%$ \\
\hline 63.437 & 2008 & $7 \%$ & $4 \%$ \\
\hline 79.569 & 2010 & $9 \%$ & $4 \%$ \\
\hline 81.377 & 2012 & $10 \%$ & $3 \%$ \\
\hline
\end{tabular}

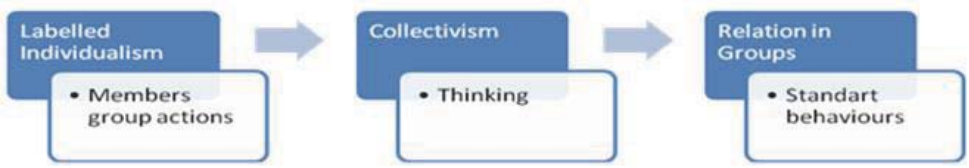

Figure 1: Bradler\& Sediss, Individualism and organizational behavior The report Company: Kingston, Ontario, 1989. ${ }^{1}$

1 Bradler\& Sediss Individualism and organizational behavior The raport Company: Kingston, Ontario, 1989. 
What are the basic differences in university education (e.g University of Vlora) and its role in society based on knowledge, intelligence and management of trade market. According to student's intelligence achievements including practices, homeworks or research studies which are implemented in certain institutions such as Municipality of Vlora, in financial institutions, banking system, SME.It is all done to find a solution for a non-loss of students Intelligence based on the trade market demands. The evidences above are shown in the charts.

\section{Conclusions}

In series of difficulties in Albania,specifically in Vlora Region south territory the surveys are done, emphasizing here the relationship betweeeen students intelligence,universities as fundamental organ in society developments and the trade market managements. The most efficient data extended by

The Organization for the development of the student career which is operating in Vlora region which is financed by WB and Vlora University itself is one of the main references based on.Such variables finding of students preparation in propotion with the market needs for these students are consistent with literature references .( Protocol of the Ministry of Education, October, Albania 2013:Lorens Kahun, 2006 Od Modernizam do postmodernizam, Templum, Skopje : Higgins, J. M "Organizational Policy and Starategic Management of Water, $2^{\text {nd }}$ edn, Dryden New York, 1983)

Eventhough being sure that education and students intelligence in space and time is of major importance, but it is of the same vital importance the trade market and the ability of managing it wisdomly. Saying otherwise brain knowledge and intelligence is not enough without the right strategy of managements for success followed by University system and Unions too. Thus further head uninterrupted surveys must be conducted for the future, because as the proverbs say "Time and Tide wait for no man"

\section{References}

Alain Touraine ne France 1993: La Voix et le Regard: sociologie des mouvements sociaux Anthony Giddens, 1997 "Sociologjia, Cabej E, University Albania

Arendt Hannah 1998, "Between past and future".CEU press, USA 1998

Bell \&Daniell 1993 Communitarianism and Its Critics

James W.Zanden 1990 "An Introduction to sociology". Mc Graw-Hill Company, Inc

Metta Spencer 1989"Sociology", Mc Graw-Hill Company

Jay D.Techman "Family Issues, Sage publication, Dayton USA

Peter Ducker, 1985 Pregled, manila 90-91

Protocol of the Ministry of Education, October, Albania 2013

Lorens Kahun, 2006 OD Modernizam do postmodernizam, Templum, Skopje

Higgins, J. M "Organizational Policy and Starategic Management of Water, 2" edn, Dryden New York, 1983.

Hofer, C, W. and Schendel, D, Dtrategy Formulation: Analytical Concepts, West, St Paul, MN, 1983.

Industrial Performance Analysis, 1987-1988 edn, ICC Business Policy and Management Capacity,2 ${ }^{\text {nd }}$ edn Irwin, Homewood, IL,1985.

Glueck, W.F. and Jauch, L. R. Business Policy and Strategic Management, 4h, edn, McGraw-Hill, New york, 1984

Bishop, E. B "ROCE as s Tool for Planning and Contol", Long Range Planning, 2, 4, 1969, 80-7.

Tilles, S. "How to Evaluate Corporate Strategy", Harvard Business Review, 41, 4, 1963 111-21 